\title{
Stem Cells between Ethics and Entrepreneurship: How a Contested Bio-Object Became 'Normal'
}

\author{
Malin Ideland \\ Correspondence: Malin Ideland, Faculty of Education and Society, Malmö University, 20506 Malmö, Sweden
}

Received: August 11, 2014 Accepted: September 3, 2014 Available online: November 27, 2014

doi:10.11114/smc.v2i2.484 URL: http://dx.doi.org/10.11114/smc.v2i2.484

\begin{abstract}
Human Embryonic Stem Cell (hESC) research has been described by many scholars as a controversial issue. However, in Swedish media reporting, hESC research is no longer described as contested. The aim of this paper is to explore how this research field has been normalized through discursive shifts which have had effects in terms of the lack of debate around novel biotechnologies.

The article compares the reporting of Swedish newspapers on hESC research during year 2001 and onwards. The reason for this selection is that during 2001 there was a heated debate around hESC. After that point, media reporting is characterized by a lack of debate. Therefore, Swedish media reporting makes an interesting case for understanding how an ethical controversy can end. To conceptualize the contemporary lack of media reporting and debate, this paper analyzes discourses operating in news media reports during and after 2001 through studying how different researcher/subject positions and hESC bio-identities are articulated during different times, and how these open up for different issues to be, or not to be, reported and discussed. Laclau and Mouffe's discourse theory, as well as a theoretical framework of bio-objectification inspire the analysis.

The result shows how ethical and political discourses about hESC in the Swedish news media have been replaced with engineering and economical discourses. The main point is that this new discursive formation has closed opportunities for oppositional ways of talking about hESC research, for example, as an ethical issue or an area for political debate and legislation. Instead, scientific-technological-therapeutic progress has been bound to a belief in economic progress. The final part of this article discusses how this discursive change can be understood in the perspective of changing relations between the public and academia, but also how dissolving positions can open up hegemonic discourses and challenge fixed meanings.
\end{abstract}

Keywords: human embryonic stem cells, discourse analysis, bio-identity, researcher/subject positions, discourse analysis, post-academic science, media

\section{Introduction}

Human embryonic stem cell (hESC) research has been described as a controversial issue all around the world. The public, the mass media, and social science scholars have all been fascinated by the technology and its associated social, legal, and ethical challenges. The two special issues of the journal Science as Culture published in 2008 (Prainsack, Geesink \& Franklin, 2008; Geesink, Prainsack \& Franklin, 2008) constitute one sign of this interest. In one of these issues, Prainsack et al. explain why the public, as well as social scientists, are so interested in these cells: "The stem cell field is densely - and explicitly - multivalent, combining ethical, political, legal, social and cultural forces with the biological materials and processes that are its objects. This situation intriguingly parallels the pluripotent vitality that makes stem cells so special" (Prainsack et al. 2008, p. 353).

This article, however, does not discuss hESC research as special and contested, but shows how it has been normalized into a non-political/ethical object in Swedish media reports. As an illustration of the normalization of a formerly-contested technology, this paper begins with a case which exemplifies the lack of debate in Sweden: the non-discussion about cybrids, which are human-animal interspecies embryos. A few years ago, cybrid technology was considered a possible replacement for using human embryos in stem cell research and therapies (Haddow, Bruce, Calvert, Harmon. \& Marsden, 2010). In the UK, there had been a heated political debate about this mixing of humans and animals and about whether or not the embryo should be considered human (Brown, 2012). In December 2008, the Swedish National Medical-Ethical Council (SMER) recognized the issue and sent a letter to the Swedish Government 
as well as four different ministries, notifying them that Swedish law does not cover this new biomedical practice. It seemed to be both possible and legal to replace the entire cell nucleus of an animal egg with human DNA and to let this egg develop into an interspecies embryo. Nothing happened after SMER's letter had reached the government; no ministry seemed to be interested in catching the ball. In a similar way, the news media were also uninterested in the issue. The Swedish media reports contained only short paragraphs such as the following, which had the headline "Cow-human created in lab":

British researchers have created an embryo that is a hybrid of a human and a cow - right in the midst of a row in Parliament over a proposed bill supporting embryo research.

Researchers from Newcastle have injected human skin cell DNA into a cow's egg cell. They first emptied the egg cell of almost all genetic material from the cow. The embryo was then alive in a laboratory for three days.

According to The Guardian, researchers hope they have taken the first, decisive step towards creating a supply of stem cells that can be used to study diseases such as Alzheimer's and Parkinson's (Aftonbladet, 2008-04-02).

In Sweden, there was no debate on the possibilities for developing interspecies mixtures - no risks formulated nor any ethical objections to using cow eggs in human treatments. The only reporting was on a debate going on elsewhere; cybrids were of neither political, nor media interest in Sweden, and it seems as though the policy process and public debate concerning cybrids ended before it even began.

\section{$1.1 \mathrm{Aim}$}

This lack of political and media interest in cybrids raises questions about how novel biotechnologies are conceptualized in the public sphere today and about the media's responsibility for handling ethical issues. Does hESC research no longer serve as a vehicle for debates around ethical, political, and legal issues, as suggested by Prainsack, Geesink, and Franklin (2008)? In this article, the aim is to understand a discursive shift in the Swedish media reporting of hESC research. Like Sperling (2008, p. 369), I would like to ask: what, in this case, made an ethical controversy end? How has a discursive change in news media opened up and closed what particular issues are contested and discussed in hESC research? It is important to note that the discursive shift is not analyzed in terms of intentionality, neither as cause or effect of any specific event; rather, media reporting is seen as a discursive formation in which specific kinds of subjects and objects are articulated, positioned, and thereby normalized (Laclau \& Mouffe, 2001, p. 105 ff). Moreover, the discursive formation organizes what issues are loud or silent and what frameworks for regulating and discussing hESC are promoted (c.f Birch, Levidow. \& Papaioannou, 2012).

\subsection{Earlier Studies and Theoretical Framework}

\subsubsection{Changed Conditions for Post-academic Science}

The change in the media reporting of hESC research can be understood in regard to a general shift in academia. This shift, taking place during recent decades, has been described in terms of e.g., Mode II (Nowotny, Scott \& Gibbons, 2001), the triple helix (Etzkowitz \& Leydesdorff, 2000), neo-liberal (Lave, Mirowski \& Randalls, 2010), and post-academic science (Lyotard 1979/1999), of which the latter is the concept used here. Roughly all these theories build on the fundamental idea that current scientific practices are more intertwined with politics, economy, and industry than they were a few decades ago.

Since the 1980s, many countries have engaged in creating competitiveness and profitability through science and the development of high-tech innovations. This increased focus on enterprise has tended to replace previous concerns associated with welfare-state politics, as well as basic research (Jessop, 2002). Post-academic science is not seen as a neutral exploration for the truth, but as a breeding ground for innovation (Benner, 2001). ${ }^{\mathrm{i}}$

Ziman (2002) explains the post-academic science in terms of increasingly assessing research from utilitarian or economic criteria (c.f. Thorpe \& Gregory, 2010). The intertwining of different spheres of economy, politics, and science has also changed the way the news media describe research, researchers and research objects (in this case, the stem cells). For instance, the demands placed on researchers for public transparency have increased and are justified by the need for public engagement and better possibilities for researchers to get grants (Nowotny, Scott \& Gibbons, 2001).

One could imagine that more transparency would also increase the possibility for debate, but Thorpe and Gregory (2010) point out that the meaning of public participation must be understood more as a way to win political legitimacy and economic viability than 'real' public involvement in policy-making. The focus here is on understanding more of how the discourse of intertwining politics, economy, and academia has resulted in subduing, rather than stirring up, public reporting and debate in Sweden. In other words, the news media are used to illustrate some of the discursive conditions for what is possible to say about hESC research and what issues are possible to (not) talk about in public in a post-academic era.

One could argue that the historical perspective of the present article is too short; post-academic science had already 
been established in 2001. For example, Benner wrote in 2001 that the aim of research policy is to win advantages inside the growing high-tech innovation sectors on the market (Benner, $2001 \mathrm{p} \mathrm{.15)}$ ). However, the intention is to problematize this description of a linear change and show that, even in the first year of the 21st century, the financial aspect of a promising research area was very limited in media reports and that other perspectives were possible to take. By analyzing changes inside the post-academic era, it is possible to understand more about how an issue can become temporarily closed, but also how it can be re-opened for discussion (Laclau \& Mouffe, 2001).

\subsubsection{Subject Positions and Bio-identities}

In the above-described discursive formation, positions for hESC researchers, as well as the hESC themselves, become (non)available. The fabrication of subject positions inside discourses is a well-known theoretical standpoint; for example, Hall writes "The subject is produced 'as an effect' through and within a discourse, within specific discursive formations and has no existence, and certainly no transcendental continuity or identity from one subject position to another" (Hall, 1996, p. 23). This means that the conditions for how we perceive, e.g., stem cell researchers depend on how the discursive position is constructed. The subject position is not fixed but, rather, articulated within a specific order of discourses (Laclau and Mouffe (2001). Drawing on these theories, the question is how subject positions for stem cell researchers are constructed in the media reporting in different temporary contexts and whether (and how) they have changed while the research has been described more in terms of post-academic science? Helmreich (2008) argues that:

...new life science commodities - e.g. therapeutic molecules, genome sequences, and pharmaceuticals that promise future health-require a reinvigorated analysis of capitalist practices as well as of the correlated kinds of citizen, corporate, and scientific subjectivities that are materializing alongside such activities (Helmreich, 2008, p. 464).

In this article, the interest is not only in understanding constructions of identities for humans; the discourse also limits and enables what characteristics are connected to the bio-object. Bio-object is meant as "...sociotechnical phenomena where we see a new mixture of relations to life or to which 'life' is attributed" (Webster, 2012, p. 1). Examples of these are transgenic animals, genetically tested foetuses, synthetic biological material or, as in this case, human embryonic stem cells. As bio-objects, stem cells have both internal and social orders and orderings, but they are contingent and shifting (Tamminen \& Vermeulen, 2012). Just as, for example, Hall (1996) describes how discourses construct (im)possible subject positions for humans, discourses construct (im)possible so-called bio-identities for stem cells. They are ascribed meaning and value through discursive work in order to stabilize the sometimes-contrasting bio-identities (Holmberg et al, 2011; Vermeulen et al, 2012; Mulinari et al, in press). Beltrame (2013, p. 402) states that "The stabilization of bio-objects in the epistemic domain is strictly connected with the ordering of society, because these objects embed ethical, cultural, and political issues." This means that in different discourses, the bio-identity is fabricated in different ways; the discourses limit and enable use of the bio-object in research, as well as what questions can be raised in the mass media (cf. Lysaght \& Kerridge, 2012). Are hESCs political and ethical objects or merely tools for stem cell therapies and research (cf. Eriksson and Webster, 2008)? Through deconstructions of these, we can understand more of how discourses serve to govern what is discussed and not discussed in media reporting. Webster (2012, p. 3) emphasizes the need to "...look in detail to the way in which life is made an object in different settings both inside and outside of the current truth regime of the contemporary biosciences."

However, the media's discursive construction of bio-identities is not unidirectional. The question is both how the media discourse constitutes the positions and how the positions (re)produce the discourse (cf. Leydesdorff \& Hellsten, 2005). The notion of bio-identities is intended to help us understand more about how an object becomes established, but also how it can be dissolved and assume a new identity. This perspective on positions can be translated into how researcher/subject positions are established and negotiated through circulating in public debates.

\section{Method}

\subsection{Data}

This article compares the reports of newspapers on hESC research during 2001 and onwards. This comparison illuminates a discursive shift after a heated debate in 2001. The origin of this debate was a request from the government to the Swedish Research Council to propose guidelines for legislation concerning the technology. This request, in combination with a representative of the Christian Democratic party, compared embryo use to the experiments of Nazi Germany, causing the chief editor of the leading Swedish newspaper, Dagens Nyheter, to invite/force political parties to express their opinion on $\mathrm{hESC}$ research. A long debate and related media reporting followed; $\mathrm{hESC}$ research was, at this point, a public and political issue. Today, stem cell research is not debated in Swedish newspapers; the debate ended with the Research Council's proposal to allow the use and creation of embryos at the end of 2001. After that, hESC research has only been reported on in short paragraphs, and there has been no actual debate. Not even the issue of using cybrids for stem cell therapies was discussed which had been causing heated debates elsewhere, for example, in 
Denmark and in the UK.

To understand and conceptualize the contemporary lack of media reporting and debate, this paper analyzes discourses operating in news media reporting during and after 2001, through studying how different researcher/ subject positions and hESC bio-identities are articulated during different times. Furthermore, it considers and discusses what kinds of ethico-political issues could be discussed inside different discursive formations. The main empirical data comes from newspaper articles published between 2002 and 2012. This means that other media, e.g., social media, radio and TV programs, and popular science journals have not been objects for analysis in this article.

The newspaper articles have been found partly by using the search engine Retriever (which covers most of the newspapers in Sweden) and partly by carrying out specific searches of two influential newspapers in Sweden: the tabloid Aftonbladet and the morning paper Dagens Nyheter. These specific newspapers were chosen because they influence the Swedish news agenda, although they do differ. Aftonbladet is a Social Democratic tabloid, while Dagens Nyheter is an independent morning paper (with a liberal heritage). They could be considered as placed on opposite sides of the political spectrum, but my point in using them together is to show that the same discourses are operating in both papers. In Retriever and on the newspapers' own websites, I searched with word strings such as stem cell, stem cell technology, stem cell treatment, regenerative medicine, cybrid, cloning, pluripotency, ips cell. The search result of the two newspapers differed: Dagens Nyheter got 239 hits on stem cell, compared to Aftonbladet's 8. Stem cell research gave 134 hits at Dagens Nyheter and only 64 in Aftonbladet. This difference is illustrative for the two papers; Dagens Nyheter has much more developed science journalism than Aftonbladet, and provides more analytical piecesii ${ }^{\mathrm{i}}$. From all these hits, articles addressing biomedical issues were selected and analyzed. This means that articles on, for instance, meat production through stem cell technology were put aside. Articles cited in the result section were selected as representative for the discourses during different time periods, although I am fully aware that there certainly are contradictory messages.

Another source of empirical data are the press communiqués from two universities: Lund University (Faculty of Medicine) and the Karolinska Institute. These two universities host the most successful stem cell research milieus in Sweden, and have received strategic grants for stem cell research from the government in 2009. Here, I have read headlines for all press communiqués from these medical faculties and extracted those concerning stem cells and regenerative medicine. This empirical data also illustrates that the same discourses are operating in different texts from different communicative contexts. Of course, this is a different type of media outlet than that of the newspapers, but the intention here is not to do a genre analysis, but to discuss a more general discursive shift present on different levels and in diverse contexts in media reporting.

The media data from 2001 was collected in a study conducted in 2002 and reported in Ideland (2002). At that time, all articles about stem cells from the written press were collected and analyzed in terms of whose voice was represented in the reporting and debate and how different individuals became actors in the game. The articles were also analyzed in terms of what themes were expressed and what themes were silenced. The entire body of data from 2001 has not been re-analyzed for the present paper, but the results from the study work as an analytical comparison point for understanding contemporary media reporting on hESC. It is used to story up to the present, to contribute to the analysis of the contemporary lack of debate around hESC in Sweden. Extracts from the articles from 2001 are included in the result as a way to illustrate an alternative discursive formation, in which other subject positions and bio-identities were available and thus also other questions possible to discuss.

\subsection{Analysis}

The main analysis focuses on how stem cell researchers and stem cells are described, what subject positions and bio-identities are available in different discourses, and how they are established and dissolved during different periods. Through analysing these different positions, the intention is to contribute to the understanding of what discourses - meaning the possibilities and constraints of what is possible to say and do - that are orchestrating the media reports on hESC and thus inviting and excluding the raising of ethico-politico issues. The discourse analysis is inspired by Laclau and Mouffe's (2001) work on discursive struggles ${ }^{\mathrm{iii}}$; how a discursive formation (cluster of discourses) is established and challenged through different articulations of the "truth" (in a Foucauldian sense: "normal knowledge"). Throughout the constant struggle for the truth, discourses become temporarily fixed through closures of the meaning, e.g., hESC as either "human life" or "biological material" or, for that matter, the stem cell researcher as medical healer or businessman. Diverse subject positions are possible inside different discourses (Laclau \& Mouffe, 2001 p. 109). This is also when the framework of the bio-object is useful, since it emphasizes how an object with a seemingly stabile meaning/identity rather is flexible and discursively constructed (Vermeulen et al, 2012; Webster, 2012). By analyzing these positions, possibilities and constraints for debate become illuminated.

The analysis focuses on how discursive formations, subject positions, and bio-identities change since they are objects for discursive struggles. Based on a comparative analysis of available positions in different times, this paper maps 
discourses that are operating in the temporary discursive formation, and how these open up for different issues to be (or not to be) reported and discussed (e.g., economical, ethical). Analytical questions guiding the study are: what attributes are articulated in relation to stem cell researchers in the newspapers during different times? What attributes are articulated to the stem cells in themselves? This categorizing of different positions was the first step of the analysis. The second step was to study how these positions were constructed in different discourses, and how these discourses operate together in discursive formations. The final part of the article discusses how changing formations can be understood in the perspective of changing relations between the public and academia, but also how dissolving positions can open up hegemonic discourses and challenge fixed meanings.

\section{Results}

This results section begins with an analysis of the discursive formation operating during the debate described above in 2001, pointing out three discourses orchestrating the media reports. This is followed by an analysis of what has happened after that specific debate, again pointing out three powerful discourses, and how the new, different discursive formation closed the opportunity for debating hESC in the Swedish news media,

\subsection{Heated Debate 2001: Expectations for an Ethically Contested and Politically Regulated Bio-object}

During 2001, the media reporting and debate on hESC research was relatively intense compared to how bio-medical issues are typically treated in Sweden. This intensity can partly be understood in relation to international influences; in the US, President George W. Bush had announced that only already-existing stem cell lines in the world should receive federal research funding. Creation of new lines from embryos was seen as violating human dignity; however, the spillover from the American to the Swedish debate was not so much about human dignity as it was about the fact that 24 of the existing 60 stem cell lines were to be found in Swedish research labs. Besides the American money involved, issues about economics and commercialization were quite absent from the Swedish media debate and reporting in 2001 (Ideland, 2002). Another reason for the intense reporting was, as described in the introduction, that the chief editor of Dagens Nyheter invited politicians to take a stand on the issue. The origin of the invitation was that representatives of the Christian Democratic Party had questioned the research and called for new legislation on the use of human embryos. In this section, I analyze what subject positions and bio-identities were available during the debate and how they were constructed inside and through the discourses of expectations, ethics, and politics.

The first discourse identified is the expectation discourse, the cultural construction of hope for medical progress. Several STS scholars have shown how reporting and debates around hESCs and other novel biotechnologies have been characterized by technologies of hope and expectations. Notions of medical progress and future possibilities operate inside the discourse; expectations are performative (Michael, 2000). Through different discursive articulations such as metaphors, narratives, and other signs of the promise of scientific progress and better (healthier) lives, they conjure up the future in the present (Brown, Faulkner, Kent. \& Michael, 2006, p. 2). Birch et al (2012, p. 3) have even stated that expectations are "'generative': they direct activities, provide legitimations and build interest in particular technoscientific solutions to societal problems." This discourse of expectations is, e.g., illustrated in the Swedish media by constructing the stem cell researcher as successful, offering a specific subject position inside the expectation discourse:

There hasn't been such a commotion about Professor Lars Hamberger at the Women's Clinic in Gothenburg since the first Swedish test-tube baby was born here 19 years ago.

Journalists have come all the way from the US after the US healthcare authority NIH announced that Sahlgrenska University Hospital has more stem cell lines than any other single research group: 19 of the 64 stem cell lines NIH has approved (Dagens Nyheter, 2001-08-31).

Much of the reporting was in regard to Swedish researchers' leading position in the world, which can be seen as an expression of the current state of post-academic science, where competition is a guiding principle. The counting of 'approved' stem cell lines in the world, the 'owners' of which could get a share of US research money, strengthened this subject position. But also the bio-object, the hESCs, was articulated in terms of expected success, for example, in patient portraits in the newspapers: "Stem cells can lead to a revolution in medicine because they can develop into any kind of cell. For instance, new nerves can be generated for people with dementia diseases" (Uppsala Nya Tidning, 2001-12-05). The flexible and promising stem cells, in combination with successful and solid researchers, carried expectations of better medical opportunities. However, as in many other countries (e.g., Lysaght \& Capps, 2012; Lysaght \& Kerridge, 2012), there was opposition to research on the use of human embryos in an Ethical discourse. One interview with a representative of the Christian Democrats, Per Landgren, came to be a reference point for many articles concerning how fundamentalist the opposition was:

According to the Swedish Research Council's medical research ethics board, taking stem cells from extra embryos is not synonymous with taking a life. The Council argues that these embryos would have been disposed of anyway. 
According to Per Landgren, the proposal is based on the situation today, which was created by researchers, and not on ethical reasoning on the value of human life.

- But, Per Landgren argues, what is most serious here is that the board's arguments could be used to defend euthanasia and taking organs from Chinese prisoners on death row. 'It's not a crime because they're going to die anyway,'one could say (Dagens Nyheter, 2001-07-12).

Here, the politician Landgren positions the researcher, as well as the stem cells, as contested; the value of human life is threatened and the researchers are the ones to be blamed. Landgren emphasizes the problems associated with using one human life to save another-issues that have had a natural place in many national debates on the use of hESCs (Prainsack et al., 2008). Lauritzen (2005) even states that the hESC debate is choreographed, "all too familiar to the dance of abortion politics" ( $\mathrm{p}$ 26). However, in Sweden, these invitations to a 'human dignity' discussion were met with resistance in the daily newspapers. Note how the following quote uses the power of 'consciousness' to draw a line between human life (in the form of embryos) and human life (in the form of patients):

People with a Christian perspective often see the principle of human dignity itself as the issue of Christianity. From such a perspective creating or destroying an embryo may be indefensible regardless of how good the purpose is.

People who focus more on the suffering of conscious beings find it easier to accept using extra embryos in stem cell research (Dagens Nyheter, 2001-12-01).

What counts as life? When is human life worth protecting? Through referring to Landgren as a fundamentalist, and by placing the patients' suffering in opposition to the embryos' dignity, there emerged a struggle about what is not only counted as life, but also as ethical. One can say that the discourse was, in Laclau and Mouffe's (2001) words, temporarily fixed as Ethical. 'Both sides' used ethical arguments, opening up for specific subject positions (for researchers) as well as bio-identities (for hESC). Compared to the construction of opponents of stem cell research as fundamentalists, individual researchers were portrayed as nice and ordinary. In this way, together with assurances of the researchers' ethical awareness, the subject position of the stem cell researcher is constructed in terms of humanity and altruism. In the Swedish news media, Swedish researchers were talked about as the opposite of, e.g., reckless American researchers (Dagens Nyheter, 2001-11-24) or irresponsible and greedy Ukrainian stem cell therapists (Aftonbladet, 2001-11-26) — a kind of 'Bad Others' in which they could reflect the 'good' Swedish researchers (Stråth, 2000). The discourse positions the Swedish researcher as reliable and ethical, and perhaps not in need of strong regulations:

Östros is no opponent of stem cell research.

-This research gives great hope that we will be able to alleviate severe human suffering. Furthermore, Sweden leads the world in this area. I wish to stress that there is no risk that free inquiry will be threatened when ethical approval is regulated by law, said the Minister for Education (Helsingborgs Dagblad, 2001-08-31).

In the above quote, we can also see that a political discourse was operating in the debate during 2001, positioning the hESC issue in the political landscape (compared with, for example, the unwillingness to deal with the cybrid issue in 2011). Although the Social Democratic minister for Education, Thomas Östros, stated that the government does not wish to threaten 'free inquiry', a regulation process was going on concerning what kinds of bio-objects should be allowed and under what circumstances they could be produced, for example, for spare embryos and therapeutic cloning. The outcome was to accept both, though some caution was expressed in relation to therapeutic cloning.

The strong political discourse during the late 1990s and early 2000s is also illustrated by several investigations commissioned by the government. Over the course of a few years, there were investigations on xeno-transplantations, biotechnology, embryonic stem cells, genetically modified animals, and genetic integrity. Gene technology and related topics were obviously considered as political issues that should be regulated. Even if Östros' statement above indicates a trust in Swedish researchers, this discourse opens up for hESC bio-identities as an object that should be regulated through national political decisions. The 'trusted' researchers are then also positioned as subjects in need of regulation. This seemingly contradictory combination is, however, possible inside a political discourse.

In summary, based on the analysis of media reporting during 2001, three important discourses are pointed out: expectations, ethics and politics. These organized the types of questions that were possible to raise, rather than offering a single truth. Inside this discursive formation, stem cell researchers and hESCs were co-constructed as human and successful, but also as ethically and legally contested and in need of regulation. One can only speculate as to whether the positioning of Swedish stem cell researchers and stem cells specifically influenced the regulations that were made during this time, but they certainly opened up specific ways of reporting about hESC research, a topic I will return to in the concluding discussion. The next section analyzes the operating discourses and available positions for researchers and hESCs after the intense debate in 2001 had died out.

\subsection{Silenced Debate 2002-2012: Expectations for an Engineered Commodity Object}

In this section, a discursive shift in media reporting is pointed out, which is that a new discursive formation is 
orchestrating the media reporting. It is evident that the expectation discourse continued to operate alongside the discourses of engineering and entrepreneurship. The scope is also to discuss how these new discourses have pushed aside the possibilities for the discourses of ethics and politics. To illustrate how media reporting has changed after 2001, this section begins with a long quote from Dagens Nyheter's reporting on the Nobel Prize in medicine for 2012:

'... for the discovery that mature cells can be reprogrammed to be pluripotent.' This was the wording of the justification announced by the Nobel Assembly at Karolinska Institutet on Monday. Pluripotent cells, stem cells, can develop into all types of cells in the body.

In 1962, a 79-year-old Brit named John B Gurdon cloned frogs. This was possible after successful attempts to move regular cell nuclei to egg cells and the technique paved the way for what we today call stem cell research. He later discovered that cells' specialization is reversible. I---/

The most controversial issue in stem cell research has been the use of embryos. Yamanaka, born the same year Gurdon cloned his frogs, was able to avoid this in a clever way by getting skin cells to reverse their development and become stem cells /---/

'We have been given invaluable tools for increasing our knowledge about diseases and new opportunities to develop treatment methods, 'writes the Nobel Assembly (Dagens Nyheter, 2012-10-08).

In this quote, two positions each are constructed for researchers and bio-objects: the researcher as successful explorer (which also has been described above) and engineer. At the same time, the bio-object is constructed as a potent cell that is to be discovered and controlled by humans. This illustrates that the expectation discourse is still operating in a normalized, uncontested way alongside an engineering discourse. The engineering researcher and the engineered bio-object constitute a discourse in which the stem cells are tools and/or material. This is more or less mechanical, which is made clear in words like repair, recycle, reuse, and construct: "In their study, the researchers, who were collaborating with colleagues in France and Japan, used a kind of stem cell that is found in healthy spinal marrow. It turned out that these cells are able to repair injured spinal marrow” (Dagens Nyheter, 2010-10-08).

This discourse has a history in biomedicine. For instance, gene technology was an area filled with construction metaphors (building blocks, etc.). As stated above, another strong biomedical discourse concerns expectations for the future, which are performed by the exploring and engineering researcher and the explored and engineered bio-object. One can see in press communiqués from the universities, for example, how these positions come back: "The first successful transplantation of an artificial trachea. For the first time in history, a patient has received a new trachea made of synthetic material that had been coated with the patient's own stem cells" (Karolinska institute, 2011-07-07).

Expectations and engineering are also combined with the third position I wish to stress in relation to researcher subjects and bio-identities: the entrepreneur-researcher and the commodity hESC-object. The entrepreneurship discourse took on a new guise in media reports. Looking at the public stem cell discussions in Sweden, we see that, in the space of ten years, the financial driving forces for scientific development have changed from being almost dangerous to being normalized; the discourse has been temporarily fixed in a new way. For instance, in the newspapers, this now taken-for-granted discourse operates through articles on stem cell companies:

The Swedish biotech company Cellartis in Gothenburg is to start the world's first factory for the mass production of stem cells made from human embryos. /---/

Cellartis was founded in 2001 in Gothenburg by six professors who have developed research on stem cells. Today, several major private equity companies are behind Cellartis and an initial public offering is being prepared (Dagens Nyheter, 2007-01-17).

Compared to 2001, the positions of entrepreneur-researcher and the commodity-hESC are constructed as accepted and normal. In 2001, these positions were still associated with certain suspicions about the aims of the research. At that time, biomedical research was to be conducted in the name of needy patients, not in order to make economic gains. Stem cell researcher Lars Hamberg, who was chairman and shareholder in the listed company Vitrolife, and partner in Cell Terapeutics Scandinavia AB, commented on this role in 2001: "That's how it is. If one is to survive at a Swedish university, one has to prostitute oneself. One has to associate with venture capitalists" (Dagens Nyheter 2001-08-31).

Here we see a clear discursive change towards post-academic science (Lyotard, 1979/1999), inside which the stem cell industry is seen as an important cog in the national BNP machinery (Mulinari et al., in press), not as 'prostitution'. This academic industry is a global enterprise, in Sweden as well as in, for example, South Korea, which is mobilized as an example of a successful stem cell economy in the Swedish media:

Stem cells are going to be South Korea's new welfare-generating industry. This year, more than half a billion will be invested in stem cell research in the country, and that is twice the investment made last year. At the same time, the South Koreans have introduced a way of quickly approving new stem cell treatments for use in patients (Vetandets värld, P1, 2012-12-06). 
Eleven years earlier, when Swedish media reporting was intense, it would have been hard for me to imagine that Asian researchers from a country that would later become a symbol for scientific fraud in hESC research (Hwang-scandal), would be reported on in positive terms for wanting to earn money on treating severely ill people with stem cells. But in 2012, the entrepreneur-researcher is a possible and even desirable subject position. As universities have changed, becoming less Humboldt-like and more business-like, the entrepreneurship discourse has strengthened. The stem cell has taken on the guise of a commodity bio-identity, symbolizing the amalgamation of the market and academia. At the same time, the desirable subject position for researchers is the entrepreneur, who will contribute to national economic wealth. There are now very few disputes about bioeconomics like those Rose (2001) described: patenting, biopiracy, and trade with human tissues. Bioeconomics has developed into a non-contested norm in Sweden, which is visualized in the positive reporting on the marketization of hESC research in South Korea.

In media reports after 2001, we can state from the analysis of available positions for hESC and stem cell researchers that there are three strong discourses operating: expectations, engineering and entrepreneurship. The main point here is that this discursive formation has closed opportunities for oppositional ways of talking about hESC research, for example, as an ethical issue or an area for political debate and legislation. Instead, scientific-technological-therapeutic progress has been bound to a belief in economic progress. In the analysis of media reporting in 2001, the positions for the researcher, as well as hESCs, were successful, human, contested and regulated. Since that time, these positions have almost been closed, while new desirable positions as entrepreneur/commodity have become available and a new hegemonic discursive formation is organizing the media reports. In the following concluding discussion, I will discuss the effects of this discursive shift in relation to what issues related to hESC research are addressed and debated in the Swedish public sphere today.

\section{Loud and Silenced Discourses}

Based on an analysis of available positions for researcher subjects and bio-objects in Swedish newspapers and press communiqués, three discourses on stem cell researchers and the stem cell objects in media reports after 2001 are identified: expectations, engineering and entrepreneurship. This categorization is, of course, not the only one possible; for example, I could have written about a medical discourse with the researcher as a healer and the hESC as a therapeutic object. However, this discourse was not as apparent as the other three, and these characteristics are included in both the expectation and the engineering discourse. Thus, the concluding discussion elaborates on how the three discourses have pushed aside the possibilities to debate the issues surrounding hESC research and how this reflects changes in the relation between society and academia.

The expectation discourse permeates media reports both before and after 2001 and, as stated above, it operates in a performative way to construct hope and, by that, also acceptance of hESC technology. The importance of this discourse has been discussed elsewhere and above (e.g., Michael, 2000; Brown et al., 2006; Geesink et al., 2008; Birch et.al., 2012), and the discursive effects of emphasizing medical progress and scientific wonders can not be underestimated if we are to understand how critical debates around hESC research have been silenced. In the early development of hESC technology, the expectation discourse was mobilized to legitimate a new technology in 2001. In that way, at that time, this was a discourse opening up for new perspectives of technological development. Swedish media reporting then changed from describing modern biotechnologies in terms of threats against the natural order to expectations of modern medicine. Today, the discourse has been temporarily fixed, organizing what other discourses that can enter the public debate, and making it more or less impossible to contest modern biomedicine in a Swedish newspapers.

After 2002, the expectation discourse goes hand in hand with the engineering discourse, which is characterized by the idea that stem cells can be controlled and that the researcher is the one who can control them. According to media reports, the researcher-engineer's mission is not only to explore stem cells, but also to repair and reconstruct bodies. In this discourse, the stem cells are constructed as a useful material; their bio-identities have been distanced from the living embryo. In relation to this, one should not forget that one new, up-and-coming technique is iPS cells-somatic cells that have been reversed in their development to become pluripotent stem cells. They have not been derived from an embryo, but from, e.g., a skin cell. New issues concerning, e.g., the difficulties in the programming (e.g., developing into tumor cells) are however not raised inside the discourse. The positions of the researcher as an engineer and the hESCs as material are not opening up for debates about difficulties. In the discursive formation, including an engineering discourse as well as an expectation discourse, there is no room for critical engagements with the technology.

The new positions have also arisen from the new relations between science, politics, and economics. When the stem cell is no longer a matter solely for research, but also for the market, ethical committees, the mass media, politicians, etc., new positions become available while old ones disappear. Through this circulation of bio-objects into and beyond different arenas - both as discourse and material—bio-identities are negotiated (Webster, 2012; Holmberg et al., 2011). One aim of the present article is to show how new bio-identities and subject positions are constructed in a post-academic culture. Many scholars have described how biomedical research has entered a 'financescape' (Helmreich, 
2008), where the researcher is expected to act as an entrepreneur (Mulinari et al., in press), the bio-object as a selling product (Prainsack et al., 2008), and the patient as a market consumer who is supposed to make rational, informed choices (Petersen \& Seear, 2011). The discourse of entrepreneurship has definitely strengthened since 2001; today it seems to be a normalized and hegemonic discourse, backed up by expectations and engineering. In 2001, financial motives for biomedical research were viewed as suspicious by the Swedish news media, as illustrated by the talk about 'prostitution'. From a post-academic theoretical perspective (Lyotard, 1979/1999), this fear of financial contamination of the research is surprising in the $21^{\text {st }}$ century. Stem cell companies were established in 2001 but, in the media debate, they did not appear as anything worth reporting on or discussing. The positions of the bio-object as a commodity and the researcher as an entrepreneur were not available in the debate, which meant that financial aspects did not enter into the debate at all. Issues of who will benefit from the scientific and technological development, who should pay for expensive treatments, and how they can be adapted to a public health system (cf. Prainsack et al., 2008) were never raised during the one period when stem cell research was actually contested and discussed in public. Now, this still relatively novel technoscience has entered the post-academic culture and become a part of the state enterprise without a public debate around the economic consequences (Holmberg and Ideland, 2013). Public engagement has become restricted to so-called consumer-citizenship, not political citizenship (Thorpe \& Gregory, 2010). This has grown from a culture in which regulation of techno-science no longer is in the democratic system, but, as Pestre (2008) puts it, regulated by institutions outside the democratic, dialogic order-markets, courts, administrations, etc. In this new order, ethics has been hijacked by the expectation discourse, based on hype, visions, and promised futures (Rajan, 2006; Pierce, 2012).

At the same time as entrepreneurship has emerged as a hegemonic discourse operating in media reporting on hESC research, other discourses have been silenced during the ten years under study. These silenced discourses are categorized as ethics and politics. In 2001, stem cell research was constructed within an ethical frame; newspapers repeatedly pointed out that it was a technology surrounded by difficult ethical issues. Matters concerning the human dignity of the embryo were raised publicly, although stigmatizing it, as fundamentalists downplayed this debate. Ethical issues were still possible to raise, as they were inside the discursive formation (Laclau \& Mouffe, 2001; Foucault, 1981). Stem cell research, alongside other biotechnological issues, was also considered as a political issue. There were governmental debates as well as governmental investigations going on in the biomedical field. Today, the issues have left the political field. The normalization of the practice, combined with the expectation discourse, opens the door to a non-regulation of novel biotechnologies. The discussions about hESC have moved from the governmental and media arenas into those of research financiers and ethical committees. In other words, political and ethical issues have been placed behind closed doors instead of being discussed in public (Holmberg \& Ideland, 2013; Sperling, 2008). In this discursive formation, stem cell technologies have, in Mouffe's (2000) view, become de-politicized, a matter solely for the expertise.

It seems like this normalization of stem cell research and the closing of the debate has consequences for how similar technologies are (not) entering the public sphere, for example that cybrids neither become media issues nor objects for the legislative process. The bio-objectification process of hESCs, seems to have spilled over onto the cybrids to the extent that it has not even become an issue in the public sphere. The bio-identity of stem cells has gone from posing a threat to cultural boundaries between life and material, human and animal, to being valued, non-contested, commodity objects. One reason for this is the shift into a post-academic science, constructed around expectations, entrepreneurship, and a belief in engineering the human body.

Finally, I would like to raise the issue of how we can open up the closed discursive formation, the seemingly fixed positions for researcher/subjects and bio-identities. One first step could be to recognize how these positions are constructed through bio-objectification processes, and how the process has been guided and enabled by a discursive shift. These positions do not have to be closed; there are possibilities to re-vitalize them by inviting new (or old) discourses into the political processes and media reports. By creating new positions for stem cells as well as for researchers, stem cell research can once again become a public issue.

\section{Acknowledgements}

This work was supported by Riksbankens Jubileumsfond, Dnr 2010-001. I thank Tora Holmberg and my reviewers for their useful comments.

\section{References}

Beltrame, L. (2013). The Italian public debate on amniotic fluid-derived stem cells. New Genetics and Society, 32, 385-404. http://dx.doi.org/10.1080/14636778.2013.852009

Benner, M. (2001). Kontrovers och konsensus. Nora: Nya Doxa.

Birch, K., Levidow, L., \& Papaioannou, T. (2014). Self-Fulfilling Prophecies of the European Knowledge-Based 
Bio-Economy: The Discursive Shaping of Institutional and Policy Frameworks in the Bio-Pharmaceuticals Sector. J Knowl Econ., 5, 1-18. http://dx.doi.org/10.1007/s13132-012-0117-4

Brown, N. (2012). Beasting Biology: Interspecies Politics. In N. Vermeulen, S. Tamminen \& A. Webster (eds.): Bio-objects. Life in the 21st century. Gowern: Ashgate Publishing

Brown, N., Faulkner, A., Kent, J., \& Michael, M. (2006). Regulating hybrids: 'Making a mess' and 'cleaning up' in tissue engineering and transpecies transplantation. Social Theory and Health, 4, 1-24. http://dx.doi.org/10.1057/palgrave.sth.8700062

Eriksson, L., \& Webster, A. (2008). Standardizing the Unknown: Practicable Pluripotency as Doable Futures. Science as Culture, 17, 57-69. http://dx.doi.org/10.1080/09505430701872814

Etzkowitz, H., \& Leydesdorff, L. (2000). The dynamics of innovation: from National Systems and "Mode 2" to a Triple Helix of university-industry-government relations. Research policy, 29(2), 109-123. http://dx.doi.org/10.1016/S0048-7333(99)00055-4

Foucault, M. (1981). In R. Young (ed.): Untying the text. A poststructuralist reader, 48-78. London: Routledge.

Foucault, M. (1982). The subject and the power: An afterword by Michel Foucault. In H. Dreyfuss \& P. Rabinow (Eds.), Michel Foucault: Beyond structuralism and hermeneutics. Hertfordshire: Harvester Wheatsheaf.

Fox, M. (2009). Legislating Interspecies Embryos. In: S.W. Smith and R. Deazley (eds): The Legal, Medical and Cultural Regulation of the Body. Transformation and Transgression. Farnham: Ashgate

Geesink, I., Prainsack, B., \& Franklin, S. (2008). Stem Cell Stories 1998-2008, Science as Culture, 17, 1-11. http://dx.doi.org/10.1080/09505430801915448

Haddow, G., Bruce, A., Calvert, J., Harmon, S., \& Marsden, W. (2010). Not 'human' enough to be human but not 'animal' enough to be animal - the case of the HFEA, cybrids and xenotransplantation. New Genetics and Society, 29, 3-17. http://dx.doi.org/10.1080/14636770903561182

Hall, S. (1996). Who needs identity? In S. Hall, \& P. du Gay (eds): Questions of cultural identity, London: Sage.

Haran, J., \& Kitzinger, J. (2009). Modest witnessing and managing the boundaries between science and the media: A case study of breakthrough and scandal. Public Understanding of Science, 18, 634-652. http://dx.doi.org/10.1177/0963662509338324

Helmreich, S. (2008). Species of Biocapital. Science as Culture, 17, $463-478$. http://dx.doi.org/10.1080/09505430802519256

Holmberg, T., \& Ideland, M. (2013). För Sverige i framtiden. Bioobjektifiering av ny medicinsk teknologi. Sociologisk forskning, 1, 31-49

Holmberg, T., Schwennesen, N., \& Webster, A. (2011). Bio-objects and the bio-objectification process. Croatian Medical Journal, 52, 740-742.

Ideland, M. (2002). Det gäller livet. Mediernas roll i stamcellsdebatten. Stockholm: Institutet för mediestudier.

Jessop, B. The future of the capitalist state. Cambridge: Polity.

Kitzinger, J. (2008). Questioning Hype, Rescuing Hope? The Hwang Stem Cell Scandal and the Reassertion of Hopeful Horizons. Science as Culture, 17, 417-434. http://dx.doi.org/10.1080/09505430802515114

Laclau, E., \& Mouffe, C. (2001). Hegemony and socialist strategy: towards a radical democratic politics. Verso Books.

Lauritzen, P. (2005). Stem Cells, Biotechnology, and Human Rights: Implications for a Posthuman Future. Hastings Center Report, 35, 25-33.

Lave, R., Mirowski, P., \& Randalls, S. (2010). Introduction: STS and neoliberal science. Social Studies of Science, 40, 659-675. http://dx.doi.org/ 10.1177/0306312710378549

Leydesdorff, L., \& Hellsten, I. (2005). Metaphors and Diaphors in Science Communication Mapping the Case of Stem Cell Research. Science Communication, 27, 64-99. http://dx.doi.org/ 10.1177/1075547005278346

Lyotard, J.F. (1979/1999). The Post-Modern Condition: A Report on Knowledge. Manchester: Manchester University Press

Lysaght, T., \& Capps, B. J. (2012). Public discourses of stem cell science in Singapore (1997-2010), New Genetics and Society, 31, 342-358. http://dx.doi.org/10.1080/14636778.2012.662058

Lysaght, T., \& Kerridge, I. (2012). Rhetoric, power and legitimacy: A critical analysis of the public policy disputes surrounding stem cell research in Australia (2005-6). Public Understanding of Science, 21, 195-210. 
http://dx.doi.org/ 10.1177/0963662510368630

Michael, M. (2000). Futures of the present: From performativity to prehension. In N. Brown, B. Rappert, and A. Webster (Eds), Contested futures: A sociology of prospective techno-science. Aldershot: Ashgate.

Mouffe, C. (2000). Politics and passions: The stakes of democracy, Ethical Perspectives, 7, 146-150.

Mulinari, S., Holmberg, T., \& Ideland, M. (in press) Money, money, money? Stem cell research in a grant allocation process. Accepted for publication in Science and Technology Studies.

Nowotny, H., Scott, P., \& Gibbons, M. (2001). Re-thinking science: knowledge and the public in an age of uncertainty. Cambridge: Polity Press.

Pestre, D. (2008). Challenges for the Democratic Management of Technoscience: Governance, Participation and the Political Today. Science as Culture, 17, 101-119. http://dx.doi.org/10.1080/09505430802062869

Petersen, A., \& Seear, K. (2011). Technologies of hope: techniques of the online advertising of stem cell treatments. New Genetics and Society, 30, 329-346. http://dx.doi.org/10.1080/14636778.2011.592003

Pierce, C. (2012). The Promissory Future(s) of Education: Rethinking scientific literacy in the era of biocapitalism. Educational Philosophy and Theory, 44, 721-745. http://dx.doi.org/ 10.1111/j.1469-5812.2010.00736.x

Prainsack, B., Geesink, I., \& Franklin, S. (2008). Stem Cell Technologies 1998-2008: Controversies and Silences. Science as Culture, 17, 351-362. http://dx.doi.org/10.1080/09505430802514851

Rajan, K. (2006). Biocapital: The constitution of postgenomic life. Durham, NC: Duke University Press.

Rose, N. (2001). The politics of life itself. Theory, Culture and Society, 18(1), 1-30. http://dx.doi.org/10.1177/02632760122052020

Rubin, B. P. (2008). Therapeutic Promise in the Discourse of Human Embryonic Stem Cell Research. Science as Culture, 17, 13-27. http://dx.doi.org/10.1080/09505430701872962

Sperling, S. (2008). Converting Ethics into Reason: German Stem Cell Policy between Science and the Law. Science as Culture, 17, 363-375. http://dx.doi.org/10.1080/09505430802514919

Stråth, B. (2000). The Swedish of Europe as the other. In B. Stråth (Ed.), Europe and the other, Europe as the other (Multiple Europes; 10). Brussels, Belgium: P.I.E.-Peter Lang.

Tamminen, S., \& Vermeulen, N. (2012). Bio-objects and generative relations. Croatian Medical Journal, 53, 198-200. http://dx.doi.org/10.3325/cmj.2012.53.198

Thompson, C. (2006). Making Parents: The Ontological Choreography of Reproductive Technologies. Cambridge, MA: MIT Press

Thorpe, C., \& Gregory, J. (2010). Producing the Post-Fordist Public: The Political Economy of Public Engagement with Science, Science as Culture, 19, 273-301. http://dx.doi.org/10.1080/09505430903194504

Vermeulen, N., Tamminen, S., \& Webster, A. (2012). Bio-objects. Life in the 21 st century. Gowern: Ashgate Publishing.

Webster, A. (2012). Introduction: Bio-Objects: Exploring the Boundaries of Life. In N. Vermeulen, S. Tamminen and A.Webster (eds.): Bio-objects. Life in the 21st century. Gowern: Ashgate Publishing.

Ziman, J. (2002). Real Science: What it is, and What it Means. Cambridge: Cambridge University Press.

\footnotetext{
${ }^{\mathrm{i}}$ However, Mulinari et. al. (in press) describe the unvaried impact of neoliberal policy—how a marketization paradigm is challenged by other politico-moral discourses concerning bio-science, such as urge for basic and translational research.

ii Two words, however, showed similar results: 1) cybrid — which wasn't mentioned in any of the two newspapers, and 2) cloning - which got 113 hits in Aftonbladet and 122 in Dagens Nyheter. However, the notion of cloning now has a more popular meaning and is used in everyday Swedish as a metaphor for duplicity.

iii Laclau and Mouffe's theoretical framework includes a large body of analytical notions: element, moment, nodes, etc. Many of these could have been used in the analysis, but in order to avoid concepts taking over the text, I stuck with the notions of discursive formation, discourse, subject position, and also bio-identity from another related framework.
}

\section{$(\mathrm{cc}) \mathrm{EY}$}

This work is licensed under a Creative Commons Attribution 3.0 License. 